\title{
Critical Thinking Skill and Academic Achievement Development in Nursing Students: Four-year Longitudinal Study
}

\author{
Yalçın KANBAY*, Elif IŞIK*, Özgür ASLAN, Pınar TEKTAŞ**, Nurhayat KILIÇ* \\ *Artvin Coruh University Faculty of Health Science \\ ** $\mathrm{PhD}$
}

\section{INTRODUCTION}

Critical thinking is a form of thinking based on purposeful and autonomous decision-making as a result of interpretation, analysis, evaluation and sense making (Facione, 1990). To have a critical thinking skill requires a systematic, sensitive and knowledge-based process. A critically-thinking individual is an individual who does not decide immediately but postpones his/her decision, perceives his/her prejudices, questions the reliability of information, evaluates different points of view and thinks about an opinion (Gürleyürek, 2008). In order for a person to be able to achieve critical thinking by developing himself/herself, he/she needs to become aware of his/her thinking process, to be able to examine the thinking processes of others and to apply the information he/she has learned in his/her daily life (Cüceloğlu, 1998). An ideal critical thinker is a person who is curious, knowledgeable, open-minded and flexible, can make fair evaluations, investigates the reliability of the results, is honest in personal evaluations, act cautiously in the judgements he/she makes, is open to innovation, is systematic in complex issues, is diligent in searching information, is logical and investigation-focused in determining criteria, and is insistent on investigating complex situations and circumstances (Facione, 1990).

Critical thinking is a commonly used process in decision-making, and individuals should use their critical thinking skills to be able to make professional decisions (Facione and Facione, 2008).
${ }^{*}$ Correspondence to Author:

Dr. Yalçın KANBAY

Artvin Coruh University Faculty of Health Science

Tel:05309273728/(466)2121301

How to cite this article:

Yalçın KANBAY, Elif IŞIK, Özgür ASLAN, Pınar TEKTAŞ, and Nurhayat KILIÇ. Critical Thinking Skill and Academic Achievement Development in Nursing Students: Four-year Longitudinal Study. American Journal of Educational Research and Reviews, 2017,2:12.

\section{eSciencePublisher 8} eSciPub LLC, Houston, TX USA. Website: http://escipub.com/ 
Many studies have demonstrated that critical thinking skill increases the academic achievement (Tümkaya, 2011) and improves problem-solving skills (Bowles, 2000; Küçükgüçlü and Kanbay, 2011) and that students with high critical thinking scores are more successful in professional practices (Bowles, 2000). In addition to these, critical thinking skills take an important place in terms of nursing education as they enable providing reliable, effective and quality nursing care (Daly, 1998; Oerman, 1998; Paul and Heaslip, 1995).

It is observed that university education, which constitutes the step before individuals go into the professional life, does not develop critical thinking skills adequately although it has an important function in the personal and professional lives of individuals (Kanbay et al., 2012, Kanbay and Okanlı, 2017). Many studies have shown that critical thinking skills of university students are at a low level (Kantek et al., 2010; Akkuş et al., 2010; Arslan et al., 2009; Bulut et al., 2009) or generally at a medium level (Beşer and Kıssal, 2009; Küçükgüçlü and Kanbay 2011; Korkmaz, 2009; Şen, 2009; Çetin, 2008; Kanbay et al., 2013).

Critical thinking skills enable individuals to question and accept the information and to make effective decisions by developing alternative points of view. In this respect, individuals should gain critical thinking skills to be able to critically approach the information at all stages of education from pre-school education to higher education (Akça and Taşçı, 2009). This can only be achieved through an educational system aimed at critical thinking (Kökdemir, 2003). For this reason, critical thinking should be explained and developed in the objectives of higher education programs (Ennis, 1997).

Based on this whole literature, critical thinking was thought to have significant effects on nursing education, and the answers to the following questions were sought by planning this study with the aim of determining the development of nursing students' critical thinking skills and academic achievements during undergraduate education and examining the change of critical thinking skills according to descriptive characteristics.

- Do the mean scores of the critical thinking skills of students differ according to the follow-ups?

- Do the mean scores of the academic achievement of students differ according to the follow-ups?

- Is there a relationship between the mean score of critical thinking and academic achievement score according to the follow-ups?

- Does critical thinking skill differ in terms of descriptive characteristics according to the follow-ups?

\section{METHOD}

Research Type: This is a longitudinal study.

Population and Sample: Undergraduate nursing students receiving education with a classical education model at a university constituted the population of the study. After receiving the necessary permissions, 4 followups were performed with the same data collection tools from the same students for four academic years. During the data collection process, the $1^{\text {st }}$ follow-up was performed at the beginning of the first academic year, and the $2^{\text {nd }}$, $3^{\text {rd }}$ and $4^{\text {th }}$ follow-ups were performed at the end of the $2^{\text {nd }}, 3^{\text {rd }}$ and $4^{\text {th }}$ academic years. Thus, the whole undergraduate education of the students was aimed to be included in the study process. No sampling method was employed in the study, and all first-grade nursing students who accepted to participate in the study (a total of 73 students) were included in the scope of the study. However, 46 (n:46) students constituted the sample of this study because there were students who left the school or went to other universities for various reasons in the following school year or who wanted to leave the study. Data collection forms were distributed to students who agreed to participate in the study by informing them about the purpose of the 
study, data collection forms, duration of the study and the need to apply the same procedure for four years, and they were asked to fill out the forms completely. The data collection stage was calculated as an average of 12 minutes for each individual.

Data Collection Tools: The "descriptive characteristics form", "student transcripts" and the "California critical thinking disposition inventory" were used in collecting the data.

Descriptive characteristics form: It is the form which is formed by the researchers as a result of the literature review, including the demographic characteristics of the students who participated in the study.

Student transcripts: It is the form that shows the academic achievements of the students during the year and on which the student's academic achievement is calculated over 4 .

California Critical Thinking Disposition Inventory: It is a scale developed by Facione et al. and used to evaluate the critical thinking level of the person. Questions 5, 6, 9, 11, 15, 18, 19, 20, 21, $22,23,25,28,33,36,41,43,45,49$ and 50 in the scale were calculated by being reversely scored (Facione et al., 1994). The validity and reliability studies of the scale in Turkey were performed by Kökdemir in 2003. The scores obtained from the subscales are calculated by multiplying the total score obtained from each subscale by 10 and then dividing by the number of items in the subscale. The total score obtained from the scale is calculated by the sum of the scores obtained from the subscales. It can be said that the general critical thinking disposition of those with less than 240 (40x6) points in the evaluation was low, those with a score between 240 and 300 points had medium-level critical thinking disposition, and those with scores higher than $300(50 \times 6)$ had higher dispositions. The internal consistency coefficient (alpha) of the scale consisting of 6 dimensions and 51 items was found to be .88 (Kökdemir, 2003).

Evaluation of the Data: The analysis of the data was performed in the SPSS 17.0 environment using number, mean, percentage, the repeated measures ANOVA, correlation analysis, and Mann-Whitney $U$ analysis.

Ethical Aspect of the Study: Written permission was obtained from the institution where the study was carried out, and verbally informed consent was obtained from the participants. Participants were informed that the study did not pose any material or moral risk in terms of the sample.

\section{FINDINGS}

During the initial period of the study, the students' ages ranged from 20 to 28 years, and the age average was $22.8 \pm 0.2$ years. While $69.9 \%$ of the sample consisted of females, the ratio of males was $30.4 \%$. While $63 \%$ of the students lived in the city, $37 \%$ of them lived in villages and towns. While the maternal educational status of $87 \%$ of the students was primary education, the maternal educational status of $13 \%$ of them was secondary education. $63.1 \%$ of the fathers were primary school graduates while $36.9 \%$ of them were secondary school graduates. $10.9 \%$ of the students had a low income level while the rest of them had a medium income level.

Table 1. Critical thinking skills of students according to the academic year

\begin{tabular}{|c|c|c|c|c|c|c|c|c|}
\hline & \multicolumn{2}{|c|}{$1^{\text {st }}$ Grade } & \multicolumn{2}{|c|}{$2^{\text {nd }}$ Grade } & \multicolumn{2}{|c|}{$3^{\text {rd }}$ Grade } & \multicolumn{2}{|c|}{$4^{\text {th }}$ Grade } \\
\hline $\begin{array}{l}\text { Critical Thinking } \\
\text { Skill Level }\end{array}$ & $\mathbf{n}$ & $\%$ & n & $\%$ & $n$ & $\%$ & $\mathbf{n}$ & $\%$ \\
\hline Low & 1 & 2.2 & 2 & 4.3 & 5 & 10.9 & 3 & 6.5 \\
\hline Medium & 41 & 89.1 & 38 & 82.6 & 39 & 84.8 & 40 & 87.0 \\
\hline High & 4 & 8.7 & 6 & 13.0 & 2 & 4.3 & 3 & 6.5 \\
\hline
\end{tabular}


In the $1^{\text {st }}$ grade, while $2.2 \%$ of the students had a low-level critical thinking skill score, $89.1 \%$ of them and $8.7 \%$ of them had medium-level and high-level critical thinking skill scores, respectively. In the $2^{\text {nd }}$ grade, $4.3 \%, 82.6 \%$ and $13 \%$ of the students had low-level, medium-level and high-level critical thinking skill scores, respectively. In the $3^{\text {rd }}$ grade, $10.9 \%, 84.8 \%$ and
$4.3 \%$ of the students had low-level, mediumlevel and high-level critical thinking skill scores, respectively. In the $4^{\text {th }}$ grade, $6.5 \%, 87 \%$ and $6.5 \%$ of the students had low-level, mediumlevel and high-level critical thinking skill scores, respectively. The large part of the sample had medium-level critical thinking skill scores during their undergraduate education (Table 1).

Table 2. The change of the mean scores of critical thinking and academic achievement according to the academic year and the relationship between critical thinking and academic achievement

\begin{tabular}{|c|c|c|c|c|c|c|c|}
\hline \multirow[b]{2}{*}{ Grade } & \multicolumn{2}{|c|}{ Critical Thinking } & \multicolumn{2}{|c|}{$\begin{array}{c}\text { Academic } \\
\text { Achievement }\end{array}$} & \multicolumn{3}{|c|}{ Significance } \\
\hline & Mean & SD & Mean & SD & $\mathbf{r}$ & $\mathbf{r}^{2}$ & $\mathbf{p}$ \\
\hline $1^{\text {st }}$ grade & 272.73 & 2.82 & $2.25^{\mathrm{a}}$ & 0.06 & 0.37 & 0.14 & 0.806 \\
\hline $2^{\text {nd }}$ grade & 273.34 & 3.18 & $2.35^{b}$ & 0.06 & 0.40 & 0.16 & 0.790 \\
\hline $3^{\text {rd }}$ grade & 271.31 & 3.35 & $2.56^{c}$ & 0.05 & 0.40 & 0.16 & 0.793 \\
\hline $4^{\text {th }}$ grade & 272.34 & 3.47 & $2.73^{d}$ & 0.06 & 0.84 & 0.71 & 0.579 \\
\hline \multirow{2}{*}{ Significance } & \multicolumn{2}{|c|}{$F=0.162$} & \multicolumn{2}{|c|}{$F=8.342$} & & & \\
\hline & \multicolumn{2}{|c|}{$p=0.922$} & \multicolumn{2}{|c|}{$\mathrm{p}=0.000^{*}$} & & & \\
\hline
\end{tabular}

While the mean score of the critical thinking dispositions of students was $272.73 \pm 2.82$ points in the 1st grade, it was $273.34 \pm 3.18$ points, $271.31 \pm 3.35$ points and $272.34 \pm 3.47$ points in the 2nd, 3rd and 4th grades, respectively. According to the grades, there was no statistically significant dif-ference between the mean scores of the critical thinking dispositions of students $(p>0.05)$. The mean scores of the academic achievement of students statistically significantly $(p<0.000)$ in-creased as they proceeded to next grade. While the mean score

of academic achievement was $2.25 \pm 0.06$ points in the 1st grade, it was $2.35 \pm 0.06$ points, 2.56 \pm 0.05 points and $2.73 \pm 0.06$ points in the 2 nd, $3 \mathrm{rd}$ and 4 th grades, respectively. When the relation-ship between the mean scores of the critical thinking skill and the mean scores of the academic achievement of students was examined, there was a low-level relationship in the 1st, 2nd and 3rd grades and a high-level relationship in the 4th grade, but this relationship was statistically insig-nificant $(p>0.05)$ (Table 2$)$
While the mean scores of the critical thinking of female students during the academic years were $272.75 \pm 3.68$ points, $270.65 \pm 3.89$ points, $272.12 \pm 3.79$ points and $271.16 \pm 4.68$ points, respectively, the mean scores of male students were $272.68 \pm 4.08$ points, $279.49 \pm 4.81$ points, $269.44 \pm 6.98$ points and $275.01 \pm 4.12$ points, respective-ly. There was no statistically significant difference between the mean scores of the crit-ical thinking dispositions of female and male students according to the academic years (Table 3).

The mean score of the critical thinking dispositions of students living in the village was $266.68 \pm 3.97$ in the 1st grade while the mean score of students living in the city was $276.27 \pm$ 3.72, and the difference between them was statistically significant $(p<0.05)$. The mean scores of the critical thinking of students living in the village in the $2 \mathrm{nd}$, 3rd and 4th grades were $269.05 \pm 4.09$ points, $267.19 \pm 5.29$ points and $265.91 \pm 4.93$ points, respectively. The scores of the students living in the city were $275.86 \pm 4.29$ points, $273.71 \pm 4.43$ points and $276.10 \pm 4.60$ 
points, respectively. There was no statis-tically living in the village and in the city in the 2 nd, 3 rd significant difference between the mean scores and 4 th grades $(p>0.05)$ (Table 3 ).

of the critical thinking disposi-tions of students

Table 3. Comparison of the students' critical thinking skills in the academic years according to their descriptive characteristics

\begin{tabular}{|c|c|c|c|c|c|c|c|c|c|}
\hline & \multirow[b]{2}{*}{$\mathbf{n}$} & \multicolumn{2}{|c|}{$1^{\text {st }}$ grade } & \multicolumn{2}{|c|}{$2^{\text {nd }}$ grade } & \multicolumn{2}{|c|}{$3^{\text {rd }}$ grade } & \multicolumn{2}{|c|}{$4^{\text {th }}$ grade } \\
\hline & & Mean & SD & Mean & SD & Mean & SD & Mean & SD \\
\hline \multicolumn{10}{|l|}{ Gender } \\
\hline Female & 32 & 272.75 & 3.68 & 270.65 & 3.89 & 272.12 & 3.79 & 271.16 & 4.68 \\
\hline Male & 14 & 272.68 & 4.08 & 279.49 & 4.81 & 269.44 & 6.98 & 275.01 & 4.12 \\
\hline & & $Z=-0.072$ & $p=0.943$ & $Z=1.432$ & $p=0.152$ & $Z=0.215$ & $\mathrm{p}=0.830$ & $Z=0.907$ & $p=0.34$ \\
\hline \multicolumn{10}{|l|}{$\begin{array}{l}\text { Place of } \\
\text { living }\end{array}$} \\
\hline Village & 17 & 266.68 & 3.97 & 269.05 & 4.09 & 267.19 & 5.29 & 265.91 & 4.93 \\
\hline City & 29 & 276.27 & 3.72 & 275.86 & 4.29 & 273.71 & 4.32 & 276.10 & 4.60 \\
\hline & & $Z=-2.082$ & $p=0.037$ & $Z=1.172$ & $p=0.241$ & $Z=0.831$ & $\mathrm{p}=0.406$ & $Z=1.354$ & $p=0.16$ \\
\hline \multicolumn{10}{|l|}{$\begin{array}{l}\text { Maternal } \\
\text { Education }\end{array}$} \\
\hline $\begin{array}{l}\text { Primary } \\
\text { education }\end{array}$ & 40 & 272.68 & 3.08 & 274.80 & 3.42 & 271.34 & 3.80 & 272.31 & 3.91 \\
\hline $\begin{array}{l}\text { Secondary } \\
\text { education }\end{array}$ & 6 & 273.08 & 7.50 & 263.63 & 6.05 & 271.05 & 4.72 & 272.51 & 5.81 \\
\hline & & $Z=-0.065$ & $p=0.948$ & $Z=1.142$ & $\mathrm{p}=0.254$ & $Z=0.196$ & $\mathrm{p}=0.845$ & $Z=0.294$ & $\mathrm{p}=0.79$ \\
\hline \multicolumn{10}{|l|}{$\begin{array}{l}\text { Paternal } \\
\text { Education }\end{array}$} \\
\hline $\begin{array}{l}\text { Primary } \\
\text { education }\end{array}$ & 29 & 273.67 & 2.97 & 272.98 & 3.56 & 271.88 & 3.88 & 277.69 & 3.19 \\
\hline $\begin{array}{l}\text { Secondary } \\
\text { education }\end{array}$ & 17 & 271.13 & 5.82 & 273.96 & 5.98 & 270.33 & 6.36 & 263.20 & 7.27 \\
\hline & & $Z=-1.172$ & $p=0.241$ & $Z=0.011$ & $p=0.991$ & $Z=0.785$ & $\mathrm{p}=0.432$ & $Z=1.855$ & $p=0.04$ \\
\hline \multicolumn{10}{|l|}{$\begin{array}{l}\text { Income } \\
\text { Level }\end{array}$} \\
\hline Low & 5 & 266.06 & 10.47 & 271.51 & 7.38 & 266.62 & 13.51 & 267.97 & 9.39 \\
\hline \multirow[t]{2}{*}{ Medium } & 41 & 273.54 & 2.93 & 273.56 & 3.40 & 271.88 & 3.45 & 272.88 & 3.75 \\
\hline & & $Z=-1.076$ & $p=0.282$ & $Z=0.159$ & $\mathrm{p}=0.874$ & $Z=0.124$ & $\mathrm{p}=0.902$ & $Z=0.406$ & $\mathrm{p}=0.65$ \\
\hline
\end{tabular}

The mean scores of the critical thinking dispositions of students whose mothers had primary education level in the $1^{\text {st }}, 2^{\text {nd }}, 3^{\text {rd }}$ and $4^{\text {th }}$ academic years were $272.68 \pm 3.08$ points, $274.80 \pm 3.42$ points, $271.34 \pm 3.30$ points and $272.31 \pm 3.91$ points, respectively. The scores of the students whose mothers had secondary education level were $273.08 \pm 7.50$ points, $263.63 \pm 6.05$ points, $271.05 \pm 4.72$ points and $272.51 \pm 5.81$ points. When the mean scores of the critical thinking skills of students whose mothers had primary and secondary education levels in the $1^{\text {st }}, 2^{\text {nd }}, 3^{\text {rd }}$ and $4^{\text {th }}$ grades were compared, there was no statistically significant change in critical thinking skill according to the maternal educational status in all four grades ( $p>0.05)$ (Table 3).

The critical thinking disposition scores of students whose fathers had primary education level in the $1^{\text {st }}, 2^{\text {nd }}, 3^{\text {rd }}$ and $4^{\text {th }}$ academic years were $273.67 \pm 2.97$ points, $272.98 \pm 3.56$ points, $271.88 \pm 3.88$ points and $277.69 \pm 3.19$ points, respectively. The scores of the students whose fathers had secondary education level were 
$271.13 \pm 5.82$ points, $273.96 \pm 5.98$ points, $270.33 \pm 6.36$ points and $263.20 \pm 7.27$ points, respectively. When the mean scores of the critical thinking skills of students whose fathers had primary and secondary education levels in the $1^{\text {st }}, 2^{\text {nd }}, 3^{\text {rd }}$ and $4^{\text {th }}$ grades were compared, there was no statistically significant change in critical thinking skills $(p>0.05)$ (Table 3 ).

The critical thinking disposition scores of students with low income levels in the $1^{\text {st }}, 2^{\text {nd }}, 3^{\text {rd }}$ and $4^{\text {th }}$ academic years were $266.06 \pm 10.47$ points, $271.51 \pm 7.38$ points, $266.62 \pm 3.8813 .51$ points and $267.97 \pm 9.39$ points, respectively. The scores of students with medium income levels were $273.54 \pm 2.93$ points, $273.56 \pm 3.40$ points, $271.88 \pm 3.45$ points and $272.88 \pm 3.75$ points, respectively. When the mean scores of the critical thinking skills of students with low and medium income levels in the $1^{\text {st }}, 2^{\text {nd }}, 3^{\text {rd }}$ and $4^{\text {th }}$ grades were compared, there was no statistically significant change in critical thinking skills $(p>0.05)$ (Table 3$)$.

\section{DISCUSSION}

The nursing profession is a profession in which critical decisions need to be taken quickly by its nature. Critical thinking is a skill that helps the nurse to take critical decisions and is intended to be developed during the nursing education process. Therefore, nurses are expected to have a high level of critical thinking skills. Although it is emphasized that critical thinking skill is important for nursing, how this skill can be improved still seems to be an important problem for nursing educators because it is observed in many studies that the critical thinking skill scores of both nurses and nursing students are at a low level (Kaya et al., 2017; Kantek et al., 2010; Akkuş et al., 2010; Fero et. al., 2010) or at a medium level (Beşer and Kıssal, 2009; Küçükgüçlü and Kanbay, 2011; Kanbay et al., 2011; Korkmaz, 2009; Şen, 2009; Çetin, 2008; Kanbay et al., 2013). Similarly, it is also observed in this study that most of the students' critical thinking skill scores are at a medium level during nursing education (Table 1). In this study which addresses a process involving the entire nursing education of students, it is observed that the mean scores of the critical thinking skills of students generally start at the medium level and also end at the medium level.

In addition to the fact that the critical thinking skills of nursing students are not at the desired level, similar emphasis is placed in the studies carried out with other student and profession groups. In the studies that researchers carried out with the academic staff (Kanbay et al., 2012), preservice teachers (Açışlı, 2016; Ekinci and Aybek, 2010; Güven and Kürüm, 2008; Gülveren, 2007), teachers (Polat, 2017), postgraduate nursing students (Öztürk and Ulusoy, 2008), midwifery students (Pınar et al., 2017), students of vocational school of health services (Arslan and Ancın, 2016) and nurses (Işık et al., 2012; Arslan et al., 2009), they state that the critical thinking skills of the groups in question are at a low or medium level. These findings indicate that critical thinking education should be based on basic education by including professional efforts and educational policies in order to maximize the critical thinking skills of individuals.

Although increases and decreases were observed in the mean scores of the critical thinking disposition of students in the form of $273.34 \pm 3.18$ points, $271.31 \pm 3.35$ points and $272.34 \pm 3.47$ points (Table 2 ), respectively in the $2^{\text {nd }}, 3^{\text {rd }}$ and $4^{\text {th }}$ grades while the relevant mean score was $272.73 \pm 2.82$ points in the $1^{\text {st }}$ grade, there was no statistically significant difference in these decreases ( $p>0.05)$. This is an important finding in terms of indicating that students who have started their undergraduate education with medium-level critical thinking skills also graduate with medium-level critical thinking skills. Similar to this finding, in the study of Kaya et al. (2017) in which they measured the critical thinking skills of nursing students at the beginning and end of the academic year, they determined that there was no statistically significant improvement in the critical thinking skills of students. Similarly, in the study of 
Kanbay et al. (2013) in which they compared the critical thinking skills of $1^{\text {st }}, 2^{\text {nd }}, 3^{\text {rd }}$ and $4^{\text {th }}$-grade students, they could not find a statistically significant difference according to the grades.

Although critical thinking is one of the important outcomes of nursing education, and nursing education is expected to develop critical thinking skills, the lack of the development of the students' critical thinking skills in this study is considered to be an important finding in terms of indicating that nursing education is insufficient with respect to developing critical thinking. This is thought to be due to the fact that critical thinking is not included in nursing education and critical thinking is not defined within the didactic education model.

Similarly, it is stated in the studies carried out that nursing education does not develop the critical thinking skill, that the curriculum should be addressed with an approach based on critical thinking, that the courses in the curriculum should aim at critical thinking and that the methods that directly improve critical thinking skill should be used (Kanbay et al., 2013).

When academic achievement development according to the grades is examined, it is observed that the students' academic achievement significantly improves as they proceed to next grade $(P<0.001)$. While the mean score of academic achievement was 2.25 \pm 0.06 points in the first grade, it was $2.35 \pm 0.06$ points, $2.56 \pm 0.05$ points and $2.73 \pm 0.06$ points in the $2^{\text {nd }}, 3^{\text {rd }}$ and $4^{\text {th }}$ grades, respectively (Table 2). This finding may be due to the positive effect of nursing education on academic achievement and may be due to the increase in students' social adaptation to school and profession as they proceed to next grade. Students who are new to the school may experience difficulties in adaptation and may not be able to reveal themselves academically because of various reasons such as separation from family, coming into a foreign environment, economic troubles and change of lifestyle. Therefore, it is expected that their academic achievement in the first years is low. This finding should not be ignored in terms of researchers who investigate the relationship between academic achievement and various variables because it is thought that the fact that the student's academic achievement is perceived as low in the first years due to the above-mentioned problems may lead to the misevaluation of the findings in the studies investigating the relationship between academic achievement and various variables. When the relationship between academic achievement and critical thinking skill according to the grades is examined, it is observed that there is no relationship between academic achievements and critical thinking skills of students from the first grade to the fourth grade (Table 2). When the studies examining the relationship between critical thinking skill and academic achievement in the literature are examined, some studies indicate that there is a positive relationship between these two concepts (Tümkaya, 2011; Öztürk and Ulusoy, 2008) while some studies indicate that there is no relationship (Kanbay et al., 2011).

In this study, it is observed that there is no relationship between critical thinking and academic achievement according to the academic years (Table 2). Although there is a positive and low-level relationship between the critical thinking skills and academic achievements of students in the $1^{\text {st }}, 2^{\text {nd }}$ and $3^{\text {rd }}$ academic years $\left(r^{2} 1_{1}^{\text {st }}\right.$ grade $=0.14, r^{2} 2^{\text {nd }}$ grade $=0.16, r^{2}{ }^{\text {rd }}$ grade $=0.16$, respectively) and there is a positive and high-level relationship in the $4^{\text {th }}$ academic year $\left(r^{2} 4^{\text {th }}\right.$ grade $\left.=0.71\right)$, it is observed that this relationship is statistically insignificant. In the literature, it is observed that there is not a complete consensus in the studies examining the relationship between critical thinking and academic achievement. Although some studies on the subject indicate that there is not a relationship between critical thinking and academic achievement (Kanbay et al., 2011), there are also studies asserting the contrary (Tümkaya, 2011; Ip et al., 2000).

When students' critical thinking dispositions according to their gender in the academic years 
are examined, it is observed that there is no statistically significant difference between females and males (Table 3). Similarly, to this finding, Akkuş et al. (2010) state that the critical thinking skills of nursing students do not differ according to their gender while Arslan and Arcın (2016) state that the critical thinking skills of students of the vocational school of health services do not differ according to their gender.

When students' critical thinking skills according to the place of living are examined, among $1^{\text {st }}$ grade students, the critical thinking skills of students living in the city are statistically higher compared to students living in the village $(p<0.05)$. Nevertheless, there is not a significant difference in other grades. This finding is consistent with the literature. Studies carried out show that there is no relationship between the place of living and critical thinking skill (Dil and Öz, 2005).

It is observed that the maternal educational status and paternal educational status of students are not associated with the critical thinking skill in all 4 measurements (Table 3 ). In the study of Dil and Öz (2005) carried out with nursing students, similarly to this study, they stated that parental educational status does not affect the student's critical thinking skill.

The mean scores of the critical thinking skills of the groups with low and medium income levels did not differ in the measurements (Table 3). On the other hand, Akkuş et al. (2010) indicate that the mean scores of the critical thinking skills of students with a low income level are higher when compared to other groups.

\section{CONCLUSIONS and SUGGESTIONS}

According to the findings of this study in which the critical thinking and academic development of the same sample were examined during the four-year period, it was determined that;

- The mean scores of the critical thinking of students were at a medium level,
- There was no improvement in students' critical thinking skills during the four-year education period,

- The academic achievement increased as they proceeded to next grade,

- There was no relationship between critical thinking skills and academic achievement.

- The critical thinking skill did not differ according to gender, place of living (except for the $1^{\text {st }}$ grade), maternal educational status, paternal educational status and income level.

In line with these results, it is recommended;

- to investigate the methods that can increase student's critical thinking skills to the higher level,

- to apply new teaching methods aimed at critical thinking in nursing education.

Conflicts of interest: None. This research did not receive any specific grant from funding agencies in the public, commercial or not-forprofit sectors.

\section{REFERENCES}

1. Açışı, Sibel. Sınıf öğretmeni adaylarının öğrenme stilleri ile eleştirel düşünme eğilimlerinin incelenmesi. İlköğretim Online, 2016; 15(1), 273285.

2. Akça, Nazan Kılıç; Taşçı, Sultan. Hemşirelik Eğitimi ve Eleştirel Düşünme. Mersin Üniversitesi Eğitim Fakültesi Dergisi, 2009; 5(2), 187-195.

3. Akkuş, Yeliz; Kaplan, Ferhat; Kaçar, Nizamettin. Kars Sağlık Yüksekokulu Hemşirelik Öğrencilerinin Eleştirel Düşünme Düzeyleri ve Etkileyen Faktörlerin Belirlenmesi. Fırat Sağlık Hizmetleri Dergisi, 2010; 5 (15), 103-112.

4. Arslan, Gülşah G; Demir, Yurdanur; Eşer, İsmet; Khorshid, Leyla. Hemşirelerde Eleştirel Düşünme Eğilimini Etkileyen Etmenlerin İncelenmesi. Atatürk Üniversitesi Hemşirelik Yüksekokulu Dergisi, 2009; 12 (1), 72-80.

5. Arslan, Şeyda Ferah; Ancın, Vacide. Sağlık Hizmetleri Meslek Yüksekokulu Öğrencilerinin Eleştirel Düşünme Eğilimlerinin Incelenmesi, 2016; 9(2), 73-99.

6. Beşer, Ayşe; Kıssal, Aygül. Critical Thinking Disposition And Problem Solving Skills Among http://escipub.com/american-journal-of-educational-research-and-reviews/ 
Nursing Students. Dokuz Eylül Üniversitesi Hemşirelik Yüksekokulu Elektronik Dergisi, 2009; 2 (3), 88-94.

7. Bowles, Kathleen. The Relationship Of CriticalThinking Skill And The Clinical Judgment Skills Of Baccalaureate Nursing Students. Journal of NursingEducation, 2000; 39 (8), 373-376.

8. Bulut, Süreyya; Ertem, Gül; Sevil, Ümran. Hemşirelik Öğrencilerinin Eleştirel Düşünme Düzeylerinin İncelenmesi. Dokuz Eylül Üniversitesi Hemşirelik Yüksekokulu Dergisi, 2009; 2 (2), 2738.

9. Cüceloğlu, Doğan. İyi Düşün Doğru Karar Ver. 1998; 25. Baskı. İstanbul.

10. Çetin, Aylin. Yüksek Lisans Tezi, "Sınıf Öğretmeni Adaylarının Eleştirel Düşünme Gücü”. Uludağ Üniversitesi Sosyal Bilimler Enstitüsü. 2008. Bursa.

11. Daly, William. Critical Thinking as an Outcome of Nursing Education. What is it? Why is it Important to Nursing Education. Journal of Advanced Nursing, 2008; 28(2), 323-324.

12. Dil, Satı; Öz, Fatma. Hemşirelik yüksekokulu ve beslenme diyetetik bölümü öğrencilerinin eleştirel düşünme becerilerinin etkileyen faktörler. Zonguldak Karaelmas Üniversitesi Sağlık Yüksekokulu Dergisi, 2005; 1(1), 12-19.

13. Ekinci, Öznur; Aybek, Birsel. Öğretmen adaylarının empatik ve eleştirel düşünme eğilimlerinin incelenmesi. İlköğretim Online, 2010; 9(2), 816-827.

14. Ennis, Robert H. Incorporating Critical Thinking In The Curriculum: An Introduction To Some Basic Issues. Spring XVI, 1997; (3), 1-9.

15. Facione, Peter. A. Criticalthinking: A Statement Of Expertconcensus For Purposes Of Educational Assessment And İnstruction. Executive Summary 'The Delphi Report' ERIC Document, 1990; p.315423.

16. Facione, Noreen. C; Facione, Peter. A. Externalizing The Critical Thinging İn Clinica Ljudgment. Nursing Outlook, 1996; 44, 129-36.

17. Facione, Peter A; Blohm, Stephen W; Facione, Noreen.C; Giancarlo, Carol Ann F. Professional judgment Rating Form: Novice/ Internship Level Critical Thinking Abilities and Habits of Mind, 2006; Milbrae, CA: The California Academic Pres LLP.

18. Facione, Noreen. C; Facione, Peter A. 'Critical Thinking And Clinical Judgment,' From Critcal Thinking And Clinical Reasoning In The Healt Sciences: A Teaching Anthology, 2008; Milbrea CA: Published By insinht Assessment / The California Akademik Pres.

19. Fisher, Alec. Critical Thinking "An Introduction", First Published. New York, 2001; Cambridge University Press.
20. Gülveren, Hakan. Eğitim fakültesi öğrencilerinin eleştirel düşünme becerileri ve bu becerileri etkileyen eleştirel düşünme faktörleri. Doktora Tezi. Dokuz Eylül Üniversitesi Eğitim Bilimleri Enstitüsü, 2007, İzmir.

21. Gündoğdu, Hakan. Eleştirel Düşünme ve Eleştirel Düşünme Öğretimine Dair Bazı Yanılgılar.Sosyal Bilimler, 2009; 7(1), 57-74.

22. Gürleyürek, Gülnur C. Sınıf Öğretmeni Adaylarının Çeşitli Değişkenler Açısından Eleştirel Düşünme Eğilimleri, Problem Çözme Becerileri Ve Akademik Başarı Düzeylerinin İncelenmesi. Yüksek Lisans Tezi. Zonguldak Karaelmas Üniversitesi Sosyal Bilimler Enstitüsü, 2008, Zonguldak.

23. Güven, Meral; Kürüm, Dilruba. Öğretmen adaylarının öğrenme stilleri ile eleştirel düşünme eğilimleri arasındaki ilişki. İlköğretim Online, 2008; 7(1), 53-70.

24. Ip, Wan Yim; Lee, Diana T F; Lee, Iris F K; Chau, Janita $P$ C. Disposition towards critical thinking: $A$ study of Chinese undergraduate nursing students. Journal of Advanced Nursing, 2000; 32, 84-90.

25. Işık, Elif, Karabulutlu, Özlem, Kanbay, Yalçın; Aslan, Özgür. Hemşirelerde Eleştirel Düşünme Eğilimlerinin Belirlenmesi: Karşılaştırmalı Bir Çalışma. DEUHYO ED, 2012; 5(3), 96-100.

26. Kantek, Filiz; Öztürk, Nezaket; Gezer, Nurdan. Bir Sağlık Yüksekokulunda Öğrencilerin Eleştirel Düşünme ve Problem Çözme Becerilerinin Incelenmesi. International Conference on New Trends in Education and Their Implications, 2010; 186-190.

27. Kanbay, Yalçın; Işık, Elif; Aslan, Özgür; Özdemir, Handan. Akademik Personelde Eleştirel Düşünme Eğiliminin İncelenmesi. Gümüşhane Üniversitesi Sağlık Bilimleri Dergisi, 2012; 1(3), 189-201.

28. Kanbay, Yalçın; Işık, Elif; Aslan, Özgür. Hemşirelik öğrencilerinin eleştirel düşünme eğilimleri ile akademik başarıları arasındaki ilişkinin incelenmesi. Psikiyatri Hemşireliği Dergisi, 2011; 2, 123-127.

29. Kanbay, Yalçın; Aslan, Özgür; Işık, Elif; Kılıç, Nurhayat. Hemşirelik Lisans Öğrencilerinin Problem Çöme ve Eleştirel Düşünme Becerileri. Yükseköğretim ve Bilim Dergisi, 2013; 3(3), 244251.

30. Kanbay, Yalçın; Okanlı, Ayşe. The effect of critical thinking education on nursing students' problemsolving skills. Contemporary Nursing. 2017, 53:3, 313-321.

31. Kaya, Hülya; Şenyuva, Emine; Bodur, Gönül. Developing critical thinking disposition and emotional intelligence of nursing students: a longitudinal research. Nurse Education. Today, 2017; 48, 72-77. 
32. Küçükgüçlü, Özlem; Kanbay, Yalçın. Hemşirelik Öğrencilerinin Eleştirel Düşünme Eğilimleri İle Klinik Başarıları Arasındaki İlişkinin İncelenmesi. Anadolu Hemşirelik ve Sağlık Bilimleri Dergisi, 2011; 14(3), 21-25.

33. Korkmaz, Özgen. Eğitim Fakültelerinin Öğrencilerin Eleştirel Düşünme Eğilim Ve Düzeylerine Etkisi. Türk Eğitim Bilimleri Dergisi, 2009; 7(4), 879-902.

34. Kökdemir, Doğan. Doktora Tezi. Belirsizlik Durumlarında Karar Verme ve Problem Çözme. Ankara Üniversitesi Sosyal Bilimler Enstitüsü, 2003.

35. Oerman, Marilyn. H. Career and Technical Education. Journal of Nursin Education, 1998; 17(6): $322-327$.

36. Öztürk, Nezaket; Ulusoy, Hatice. Lisans ve Yüksek Lisans Hemşirelik Öğrencilerinin Eleştirel Düşünme düzeyleri ve Eleştirel Düşünmeyi etkileyen faktörler. Maltepe Üniversitesi Hemşirelik Bilim ve Sanat Dergisi, 2008; 1,15-25.

37. Paul ,Richard W; Heaslip, Penelope. Critical Thinking and Intuitive Nusing Practise. Journal of Advanced Nursing, 1995; 22(1): 40- 47.

38. Pınar, Şükran E; Aksoy, Özlem D; Cesur, Büşra; Gülseren, Dağlar. Ebelik öğrencilerinin eleştirel düşünme eğilimleri ve iletişim becerileri. Journal of Human Science, 2017; 14(2), 117-1128.

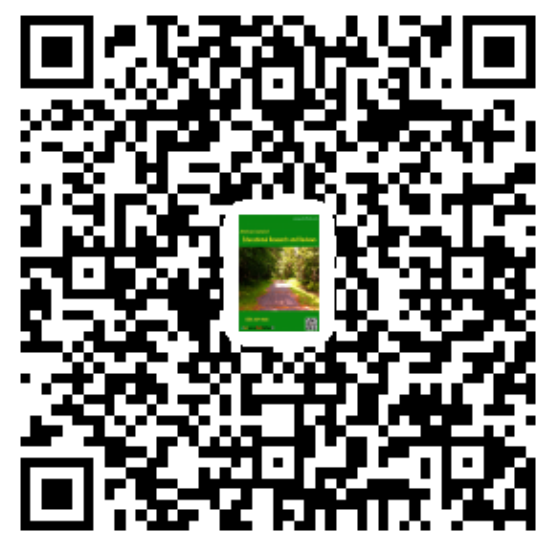

39. Polat, Musa. Yüksek Lisans Tezi. Sınıf Öğretmenlerinin Eleştirel Düşünme Eğilimleri İle Yaratıcılık Düzeylerinin Bazı Değişkenlere Göre İncelenmesi. Adıyaman Üniversitesi Sosyal Bilimler Enstitüsü, 2017.

40. Şen, Ülker. Türkçe Öğretmeni Adaylarının Eleştirel Düşünme Tutumlarının Çeşitli Değişkenler Açısından Değerlendirilmesi. Journal of World of Turks, 2009; 1(2), 69-89.

41. Şengül, Figen; Seydaoğlu, Gülşah. Hemşirelik Eğitim Modellerinin Öğrencilerin Eleştirel Düşünme Eğilimlerine Etkisi: Çok Merkezli Çalışma. Çukurova Üniversitesi Sağlık Bilimleri Enstitüsü, 2010; Adana.

42. Tümkaya, Songül. Fen Bilimleri Öğrencilerinin Eleştirel Düşünme Eğilimleri ve Öğrenme Stillerinin İncelenmesi. Ahi Evran Üniversitesi Eğitim Fakültesi Dergisi, 2011; 12 (3), 215-234. 